the end of the cut, and the stress distribution becomes much more complicated.

The stress in glass tools when cutting nitro-cellulose has been studied, and it is found that when the material is being removed in a thin shaving by a true cutting action the stress system is of a simple radial type. The colour bands are very nearly arcs of circles passing through the cutting edge as indicated in Fig. 3, and are such as would be produced by the action of a concentrated force applied at this place. They are, in fact, of the same type as those obtained when a non-axial force is applied at the apex of a wedge, giving isoclinic curves and colour bands (Fig. 5), all of which pass through this point up to the yield point of the material. The centres of the circular arcs of these latter bands all lie upon a line passing through the apex and perpendicular to the dark band shown in Fig: 5, which marks the region of no stress. They are, therefore, approximately consistent with Michell's theory of stress in a wedge, 1 and have been shown

1 Proceedings of the London Mathematical Society, vol, xxxiv., I902, and Love's "Theory of Elasticity," 2nd edition, pp. 208-209. experimentally, in the paper referred to above, to be in good agreement therewith along the line of action of the applied force. The stress system is found to be almost entirely radial and expressed by

$$
\hat{r r}=-c \cdot \frac{\cos (\alpha-\phi)}{r},
$$

along this line-where $a$ is the inclination of the outer face to the line of centres of the colour bands, and $\phi$ is the inclination of the applied force to the same face. Along each colour band $\geqslant$ is practically constant. The value of the constant $c$ is also expressible in terms of the force $P$, the angle $a$ and the angle $\gamma$ of the wedge. The stress system in the case when the material is being torn off by the action of the raking face of the wedge angle of the tool has not, so far, been made out. Experiment shows, however, that it is of a more complicated type, especially when the action is accompanied by the building up of a secondary wedge on the tool from the material torn off in a manner which is familiar to those engaged in machinery operations involving heavy cuts.

\title{
The New Building of the National Academy of Sciences, U.S.A.
}

\section{By Dr. C. D. WALCOTT. ${ }^{1}$}

T $\mathrm{N}_{1} 863$ Henry Wilson, United States Senator from Massachusetts, asked a number of men eminent in science to come together to form an organisation by which the scientific strength of the country might be brought to the aid of the government. This meeting was directly the result of an Act of Congress passed March 3, I863, incorporating the National Academy of Sciences of the United States of America. While Senator Wilson presumably had aid and suggestions from the incorporators, the bill had its inception with, and was drawn by him, and did not incorporate the Academy in any state or territory, or in the District of Columbia. It seems to have been his idea that the Academy should be national in its broadest sens ?.

The Academy has held its annual meetings in Washington at the Smithsonian Institution and its autumn meetings in other cities. Joseph Henry was president for many years and at the same time secretary of the Institution. The records and library of the Academy have been stored in several hundred boxes at the Institution, awaiting "such time as the Academy may have a building of its own where this material can be made available.

The semi-centennial in ror 3 gave new life to the activities of the Academy, and the foreign secretary, Dr. George E. Hale, proposed then that the Academy should have a home. He prepared tentative plans and had them put in shape by an architect. These plans provided laboratories and a library for the use of the Academy and resident men of science for research work.

The project was not to be long delayed, for the world war coming in ror4 changed and broadened the thought of the world. What started to be a battle of armed forces turned to competition between the countries at war in creative scientific research, looking

1 Paper read before the National Academy of Sciences on April 24.

$$
\text { No. } 275 \text { I, VOL. IIO] }
$$

to the destruction of masses instead of individuals. This led to the need in the United States of a body that could bring together the most able men in the fields of science for the solution of war problems. Dr. Hale, conceiving the need for such a service long before it was an actual necessity, proposed that the Academy take preliminary steps in the organisation of the scientific resources of the United States, and this was the beginning of the National Research Council which rendered such effective service at the request of the President of the United States during the war.

Appreciation of this service from the Academy was shown in an executive order issued by President Wilson, directing the National Academy of Sciences to continue the Council. Under this order the Research Council was reorganised on a permanent peace basis as an agent of the Academy, and the need of the Academy for a home was accentuated. Dr. Hale's precious plans were discussed at length, but the question of available funds continued. The quarters in the Smithsonian Institution, already too crowded, could not afford room for this new body, and temporary space elsewhere was found in the Munsey Building; then a residence at $\mathrm{r} 6$ th and $\mathrm{L}$ Streets, having twenty-one rooms, was secured. A little later a larger building at 16 th and M. Streets was occupied, until the present location at I 7 th and Massachusetts Avenue was leased.

Early in these renewed activities strenuous efforts were made to secure a permanent endowment and money for a building for the Academy, and a suggestion was made to the Carnegie Corporation of an endowment and building for the Academy and Research Council, resulting in an offer of 5,000,000 dollars, provided the Academy would secure a site and present satisfactory plans. The amount needed for the purchase of this site was apportioned, so that the entire country might have a part in the great enterprise. The raising of funds for the purchase of the 
ground was accomplished through the efforts of Dr. Hale, Dr. Millikan, and others.

The lot purchased by the Academy is known as Square 88 . It contains 189,755 square feet. Originally its highest point was in north-west corner and its lowest point was under water in the river at the south-east. To-day its lowest point is about 24 feet above high water and its highest $4 \mathrm{I}$ feet. The borings show that there is a fill of from 5 to ro feet where the building will stand, from 6 to 28 feet of clay and sand, and from 7 inches to 3 feet of decomposed rock.

The building planned has a frontage of 260 feet and is 140 feet deep. The height above the first floor is 60 feet. The vestibule is II by 20 feet; the entrance hall, 36 by $2 x$ feet; the central hall, 64 by 24 feet; the
Facing the Lincoln Memorial, the marble building in simple classical style will rise three stories from a broad terrace. On the first floor there will be an auditorium seating some 600 people, a lecture-hall holding $25 \circ$, a reading-room, library, conference rooms, and exhibition halls. The basement will contain a cafeteria and kitchen. The two upper floors will be devoted to offices.

The building is the gift of the Carnegie Corporation of New York, while the ground was bought at a cost of nearly 200,000 dollars through the donations of about a score of benefactors. Bertram Grosvenor Goodhue of New York is the architect. $\mathrm{He}$ is one of the best-known architects in the country, and designed the St. Thomas Church, the West Point

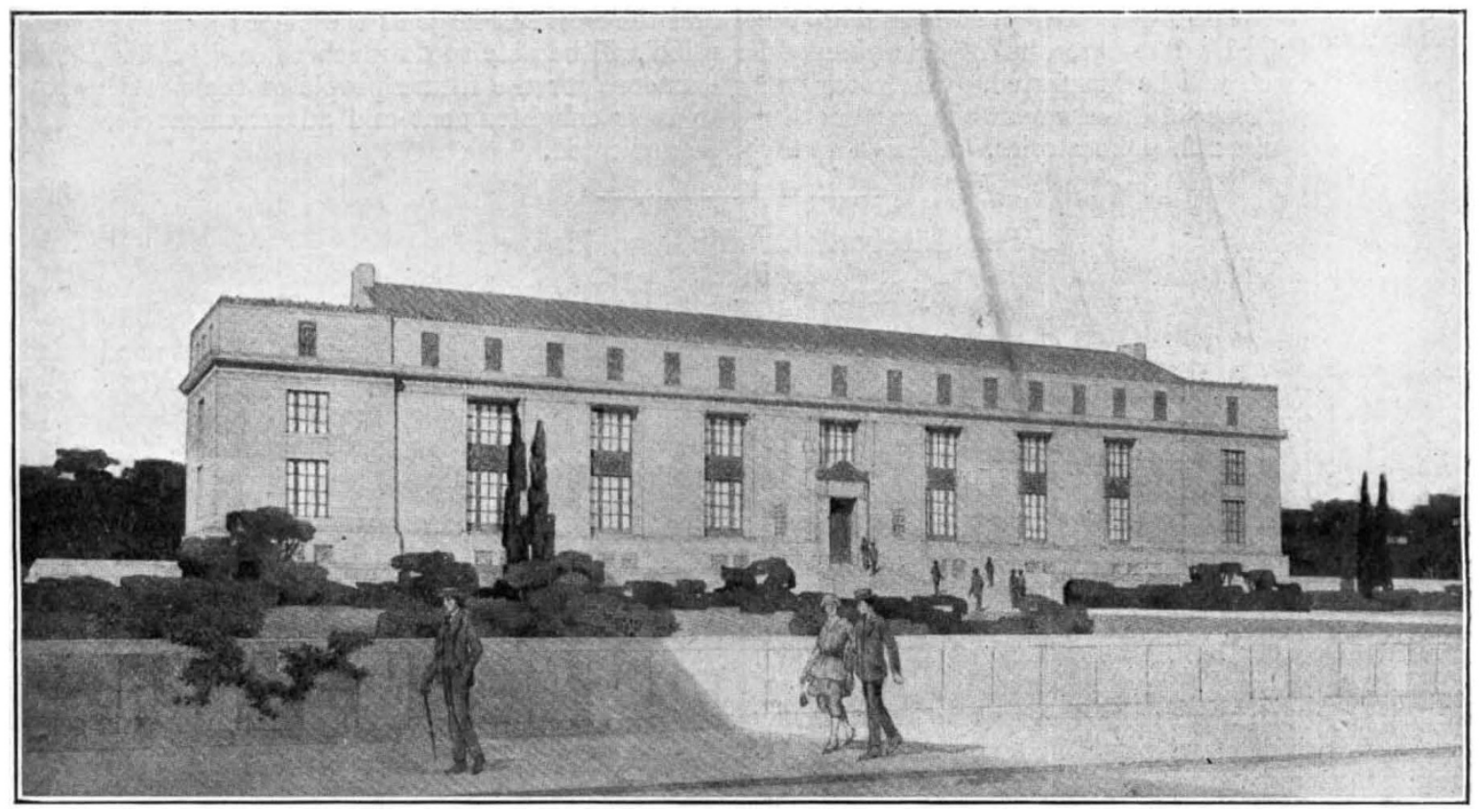

FIG. I. - New building to be erected in Washington, D.C., for the National Academy of Sciences and the National Research Council.

library, 36 by 64 feet; the lecture-room, 34 by 50 feet. The five exhibition halls range in size from 26 by 14 to 34 by 21 feet.

The total number of square feet of floor space, exclusive of elevators, doorways, and hallways, is 39,874. This includes exhibition space amounting to $\mathrm{r} 4,57 \mathrm{I}$ square feet, lecture and entertainment space of 7982 , and $\times 4,786$ square feet for administrative purposes. Every modern convenience and facility will be provided.

Having brought you thus far, let us assume that we are on our way to the annual meeting in 1924 . Walking west along B Street, half-way between 2 rst and 2 nd Streets, we find a broad walk on our right, with reflecting pools in the centre leading through a formal effect of trees and shrubs to a building in the middle of the square surmounting a series of terraces. It is the home of the National Academy of Sciences and the National Research Council-a marble structure of fine proportions, standing out in bold relief against the blue sky in the morning sunlight (Fig. I).
Building, the Nebraska State Capitol, and many other buildings. The contract for the construction of the building has been let to Charles T. Wills, Inc., of New York, and it is expected that the building will be ready for occupation in the autumn of 1923. Lee Laurie, the sculptor, has been selected to do the decorations, which will symbolise and depict the progress of science and its benefits to humanity. A series of bronze bas-reliefs will show a procession of the leaders of scientific thought from the earliest Greek philosophers to modern Americans.

On passing through the entrance hall the visitor will find himself in a lobby rotunda. Here he will see in actual operation apparatus demonstrating certain fundamental scientific facts that hitherto he has had to take on hearsay. A coelostat telescope, mounted on the dome of the central rotunda, will form a large image of the sun on the white surface of a circular table in the middle of the room. Here visitors will be able to see the sun-spots, changing in number and form from day to day, and moving across the disc as the sun 
turns on its axis. A 6o-foot pendulum, suspended from the centre of the dome, will be set swinging through a long arc, repeating the celebrated experiment of Foucault. The swinging pendulum will mark an invariable direction in space, and as the earth of the building revolves beneath it, rotation will be plainly shown by the steady change in direction of the pendulum's swing over a divided arc.

Two great phenomena of Nature, the sun and the rotation of the earth, are thus to be exhibited. Other phenomena to be demonstrated in striking form in the central rotunda are magnetic storms, earthquakes, gravitational pull of small masses, the pressure of light, the visible growth of plants, swimming infusorians in a drop of ditch water, living bacteria, and other interesting phenomena.

In the seven exhibition rooms surrounding the central rotunda, the latest results of scientific and industrial research will be illustrated. One room will be set aside for the use of Government bureaus, another for industrial research laboratories, others for the laboratories, observatories, and research institutes of universities and other institutions. The newest discoveries and advances in the mathematical, physical, and biological sciences and their applications will be shown in this living museum, in which the exhibits will be constantly changing with the progress of science. One week there may be displayed the latest forms of radio-telephony ; the next perhaps a set of psychological tests or a new find of fossils or a series of synthetic chemical compounds. Such a mutating museum will continue to attract and instruct large numbers of visitors and residents.

We call it the building for the National Academy of Sciences and the National Research Council, but in reality it should be the national home of science in America, and will be looked upon by our fellow-citizens and the world at large as the place where the creative mind will be able to do much to bring about a better existence for the future people of the world, for it is to their enlightenment and advancement that it will be dedicated.

\title{
The Internal Combustion Engine. ${ }^{1}$
}

\author{
By Prof. W. E. Dalby, F.R.S.
}

The Influence of the Internal Combustion Engine.

$T^{O}$ engineers the terms horse-power and horsepower hour have strictly technical meanings. They can be illustrated by comparing the weight and efficiency of an aircraft engine and a locomotive engine. An aircraft engine can be built with about $2 \frac{1}{2} \mathrm{lbs}$. of metal per horse-power as against approximately $250 \mathrm{lbs}$. of metal per horse-power in a locomotive engine. An aircraft engine requires about $\frac{3}{4} \mathrm{lb}$. of fuel oil per H.P. hour as against 3 lbs. of coal per H.P. hour used. by the locomotive engine, in addition to which the locomotive engine must carry about 3 gallons of water per H.P. hour. All these, of course, are round figures. It is the extreme lightness of the petrol engine in relation to its power which has made it possible to develope aircraft.

An internal combustion engine of the Diesel type is built to use heavy oils, and has provided a prime mover by means of which the submarine was able to develop so considerably during the war. Thus the internal combustion engine helped to sink our food ships, but at the same time helped to save the situation by driving the agricultural tractor. Few, perhaps, realise fully how serious was our position in I917. Horses were required for the Army and were being taken from the farms ; but the agricultural tractor replaced them at the plough and thus made it possible to maintain the necessary food supplies.

Probably the greatest effect of the internal combustion engine on our national life is its influence on road transport. Standing at Hyde Park Corner twenty years ago a motor car would have excited notice ; standing there to-day it is almost true to say that the horse-drawn vehicle has practically disappeared. The internal combustion engine is displacing the horse from the streets, and is even causing the railway companies grave concern. The chairman of one of them stated at the last half-yearly meeting that

1 From a Discourse delivered at the Royal Institution on Friday, May 26. the companies had lost 9 million tons of goods, and 6 million passengers to the motor lorry and the motor car. This is a remarkable achievement for the small I6-20 H.P. internal combustion engine which is fitted in these vehicles. During r921 about 800,000 licences were issued to vehicles propelled by internal combustion engines and the tax on them amounted to about ten million pounds.

These brief considerations indicate how profound has been and is the influence of the internal combustion engine in shaping our destinies. It has conquered the air, and has given us a prime mover useful in farming and in transport. It is influencing the policy of our railways, and will shortly so transform our outlook and our modes of life that men of to-day will appear to be separated from their boyhood not by a few decades but by a few centuries.

\section{Some Problems of the Internal Combustion Engine.}

Considering combustion from the point of view of the Kinetic Theory of gases, but without attempting to explain the nature of the differential attraction between molecules, most of the energy developed in the cylinder of an internal combustion engine arises from the fact that oxygen combines with carbon and hydrogen to develop large quantities of heat. The function of the engine is to convert as much as possible of this heat into mechanical work.

It can be deduced by the laws of gases that the molecules at $22^{\circ} \mathrm{C}$. and atmospheric pressure require 729 times the volume they occupied as a liquid. This can be illustrated by "air patterns" representing the distribution of molecules in the air. Actually the molecules are flying about at a high velocity across the vessel the sides of which they are continually bombarding and therefore exerting pressure on them.

Calculation from the kinetic theory of gases shows that at $22^{\circ} \mathrm{C}$. the oxygen molecules in the air are flying at a velocity of about $\mathrm{I} 600 \mathrm{ft}$. per second, the nitrogen 